Cinémas

Revue d'études cinématographiques

Journal of Film Studies

\title{
Introduction
}

\section{Melanie Nash}

Volume 14, numéro 1, automne 2003

Dispositif(s) du cinéma (des premiers temps)

URI : https://id.erudit.org/iderudit/008955ar

DOI : https://doi.org/10.7202/008955ar

Aller au sommaire du numéro

Éditeur(s)

Cinémas

ISSN

1181-6945 (imprimé)

1705-6500 (numérique)

Découvrir la revue

Citer ce document

Nash, M. (2003). Introduction. Cinémas, 14(1), 7-19.

https://doi.org/10.7202/008955ar d'utilisation que vous pouvez consulter en ligne.

https://apropos.erudit.org/fr/usagers/politique-dutilisation/ 


\section{Introduction}

\section{Melanie Nash}

In June 2002, the Domitor conference, ${ }^{1}$ taking place in Montreal, took as its organizing theme a familiar concept in film studies: "the apparatus." In the past, studies of early cinema have been concerned with the history of the many and various optical devices that constitute early film projection, its predecessors, and adjacent or competing visual technologies of the period. But the cinematic apparatus is not simply a technological concern, of course, unless by "technology" we refer to something more expansive, as in Herbert Marcuse's definition (1994, pp. 138139), where a technology is "a mode of organizing and perpetuating (or changing) social relationships, a manifestation of prevalent thought and behavior patterns, an instrument for control and domination." Indeed, since the 1970s, in film studies the term "apparatus" is most often invoked in a theoretical context in relation to questions of spectatorship and ideological power.

This issue of Cinémas has collected from the Montreal meeting of Domitor articles that grapple with precisely this area of intersection-between cinema history and what has become known as "grand" theory-wherein early cinema and related visual entertainments (such as the phantasmagoria, panoramas, mutoscopes) are considered in terms of their implications for theoretical models of spectatorship and/or historical reception practices that might challenge such theories. The writers included here reconsider the continuing usefulness of the concept of an "apparatus" for framing both our historical questions and theoretical extrapolations, and in relation to the kind of viewing demanded by a variety of devices, texts, and practices during the period of cinema's earliest elaboration. The value of the notion of the cinematic apparatus is not a question that 
should be taken for granted, as too much of cinema scholarship had (before the last decade or so) simply separated historiography from theory, or even set the two in irreconcilable opposition. While a rapprochement has undoubtedly taken place in more recent years, it is certainly time to consider directly how for early cinema studies the theoretical and historical can productively meet in the trope of the apparatus.

\section{The Evolving Relationship Between History and Theory in Film Studies: The Disciplinary Context for Reconsidering the (Early) Cinematic Apparatus}

In an article that is now over twenty-five years old, Rick Altman traces the major methodologies and reigning practices in U.S. film historiography of that period (the 1970s). While the then-emblematic works in cinema history that he (quite comprehensively) surveys and critiques are certainly no longer on the cutting edge of disciplinary historiography, Altman's "Towards a Historiography of American Film" nonetheless remains conceptually valuable, clearly assaying a number of important approaches to writing film history, and tackling the still troublesome issues of, for example, periodization and canon formation. Altman (1977, p. 1) writes: "No longer can a film historian deal with all the facts, nor can he $[$ sic $]$ pretend that they are objective phenomena divorced from a particular way of looking at them." Altman makes note of the consequences of each "particular way of looking at" — and, thus, of discursively constituting — cinema history. He deals with thirteen organizing principles of cinematic-historical explanation: those highlighting technology, technique, personality, a comparison between film and other arts, chronicle forms, social history, studio determinants, auteurism, film genre, ritual, legal, industrial, and sociological accounts (Altman 1977, pp. 2-21). In other words, Altman is not simply suggesting a taxonomy of popular "topics" within cinema historiography; in fact, his use of such categories does not necessarily designate a particular object of historical study, but rather identifies a privileged explanatory model applied to a variety of historical objects. In addition to outlining this variety of "theor[ies] of coherence of filmic events" (Altman 
1977, p. 2), he also examines what such theories may suppress. And, based on existing U.S. film histories at the time of the article's writing, Altman is also able to point out which types of historiographical explanation are generally deployed in relation to specific periods of film history, and with what consequences.

Judged in relation to current trends in cinema studies, what is most strikingly absent from the field of film historiography surveyed by Altman is a consideration of spectatorship itself as either an object or organizing principle for cinema history. (This topic is raised peripherally within several of Altman's categories, but is given a larger measure of attention in his discussion of "social," "ritual," and "sociological" history.) Spectatorship studies of any kind $^{2}$ had only recently come into prominence in the 1970s, with the introduction of ideological (Althusserian) and psychoanalytic (Freudian and Lacanian) theories of "subject formation" in relation to cinematic "hailing" or identificatory mechanisms, for example. And of course, the notion of a largely transhistorical cinematic "apparatus" as described by Baudry and Metz is at the centre of such mechanisms. ${ }^{3}$ The notion of theorizing spectatorship's historical specificity or historicizing spectatorship theory is a much more recent phenomenon. It is thus hardly surprising that audiences and/or spectators are considered only in diffuse and largely implicit ways both in the histories Altman surveys and in a number of his own analytical appraisals of cinema historiography. In this era, history and theory were most often deemed to be completely separate and unrelated undertakings within film studies, if not opposed ones. Yet Altman's article does both call for and itself move toward an increased self-consciousness within film studies regarding historiographical practices and the theoretical assumptions such practices entail.

More than a decade following Altman's intervention, Robert Sklar's meta-historiographical article, “Oh! Althusser!: Historiography and the Rise of Cinema Studies," explicitly takes up the traditional separation and then-recent rapprochement of history and theory in cinema studies:

More recently, as some historians have begun to utilize the approaches of theoretically grounded literary criticism, and some film scholars have developed interests 
in social historians' work, these differences have begun to diminish, though not yet through much mutual familiarity or common dialogue (Sklar 1990, p. 13).

But to a certain extent, this article describes a methodological battleground rather than a happy fusion of formerly separated fields. Sklar argues that film studies quickly became dominated by a "third generation" of academically trained scholars who were "swept away by strong theoretical winds from Europe:" "Writing 'theory' made it possible for new practitioners at all academic levels to achieve publication without having to wait to build a base of knowledge through months and years of film viewing and archival research." Sklar laments "hyperactive theory" and the disparagement heaped upon credentialed historians' positivism: "Theory wore the doctor's white coat; history sat in the waiting room, in need of diagnosis and cure" (Sklar 1990, p. 16).

Continuing his rather pessimistic depiction of this initial disciplinary peculiarity and the evolving relationship between history and theory, Sklar next draws a distinction between ("real") cinema historians and third-generation "revisionists." He discusses in different ways essays by Judith Mayne (1982) and Miriam Hansen (1983), each of which argue for a proletarian audience of early cinema, but he ultimately characterizes both as too invested in specific theoretical concerns and not "historical" enough:

On the one hand, works by revisionist film historians appear to be fueled by an underlying ideological purpose that leads them to significant absences and distortions in their use of evidence; on the other, theoretical approaches to the subject that are more sophisticated and challenging ideologically also may appear, from the perspective of academic history, arcane and abstract in terminology and woefully lacking in documentation (Sklar 1990, p. 27).

As an alternative to these options, Sklar turns away from film studies scholarship altogether to assess the work of "radical social historians" who consider early cinema 
as part of immigrant and working-class lives, as one of many sites of leisure and communal activities - the dance halls, saloons, amusement parks, and other private and commercial entertainments that have been the focus of the past decade's resurgence of historical study on working-class life and popular culture (Sklar 1990, p. 28). ${ }^{5}$

But Sklar argues that the theoretical and textual analyses of film scholars writing early cinema history need to be balanced, not replaced, with such radical social history, which itself has limitations:

[T] hese remarks point to difficulties inherent in social histories' limiting their consideration of cinema to the social interaction of persons within a theater space. Cinema in this sense is different from the saloon and the dance hall and other cultural sites valorized in radical social history of popular culture. Whatever cinema was as this type of social experience, it was also a masscommunications medium with aesthetic, ideological, and psychological dimensions. Its social contestation ultimately arose in relation to film spectatorship as a mental experience (Sklar 1990, p. 31).

In this sense, Sklar is acknowledging a need to consider spectatorship in its theoretical dimension as well. Finally, then, Sklar advocates that cinema historiography begin a serious reengagement with "Althusserian concepts not only concerning ideology as representation but also concerning its purported capacity to interpellate sujects". Invoking Benjamin to resituate cinema history at the center of "any contemporary historiography," Sklar (1990, p. 32) underlines the political importance of historicizing cultural reception.

\section{Historicizing Ways of Seeing}

To some extent Sklar's call has been answered in a number of contemporary studies that return to early cinema as a privileged site of cultural change, to the enabling conditions of visual modernity preceding and surrounding the cinematic per se, and to a reconfiguration of vision and viewers in the 19th century. 
The emergence of this intersecting domain of a specific period (early and precinema) and theoretical issue (spectatorship) into historiographical view is the result of the convergence of two largely separate strains of inquiry in film studies during the 1980s. The first of these is the theorization of cinema spectatorship itself. Relying on ideal models of ideological or psychoanalytic positioning, spectatorship theory of the 1970s and early 1980 s was concerned to establish the "universal" spectatorial effects of cinema upon such categories as subjectivity, identification, and desire. These effects were conceived as basic to the apparatus itself (projection in a darkened space, the "keyhole" effect, the immobility of the viewer, etc.) or basic to "dominant" cinematic codes and conventions (relays of looks, goal-oriented narrative arrested only by spectacle, continuity or "illusionistic" editing techniques, etc.). And whether these effects were then explained through an ideological conception of subject formation and maintenance (following Althusserian "interpellation," and considering Hollywood cinema among the ISAs), or through a psychoanalytic paradigm (Freudian or Lacanian, emphasizing dream analogies, pre-Oedipal relations, scopophilia, fetishism, sadism, disavowal of lack, fantasy, "suture," split subjectivity, Imaginary/Symbolic realms, misrecognition, etc.), they were nonetheless considered ahistorically, as fundamentally unchanging, and, in some cases, unchangeable.

Differences in viewer positioning were admitted in these models of spectatorship only insofar as predetermined positions in a capitalist or patriarchal social order were being differentiated onscreen. This led to a fundamental problem for feminist theorists, who, in denouncing an always-already patriarchal apparatus that necessarily positions the viewer as male, increasingly found reason to resist a model of spectatorship that erased a place for feminine subjectivity or female viewers' pleasure as impossibilities. In addition to calls for developing a feminist, countercinema aesthetics, theories attempting to specify female spectatorship of Hollywood cinema-as passive, masochistic, male-identified drag, a performative "masquerade," or made fluid in the oscillating subject-object positions of fantasy-have marked the development of this strain of feminist theorization. 
Totalizing models of cinema spectatorship were also challenged by an increasingly felt need to recognize real subdivisions among "the audience," to theorize spectatorial positions from an analysis of constituent social groups, and across an array of socially constituted subjectivities: how would not only gender but class position, racial or ethnic identity, or sexual orientation affect viewing? Influenced by a growing number of reception studies, sociological and/or ethnographic approaches (primarily in television studies), and the field of cultural studies, spectatorship theory from the mid to late 1980s began to grapple with the cultural heterogeneity and specificity of cinema viewing (synchronically), as well as the historical changeability and diversity of the cinematic apparatus, filmic techniques, viewing habits or experiences, and, presumably, the subject effects of cinema as an institution (diachronically). In other words, film theorists began to historicize spectatorship as both determined by and a determinant of the historical variability of social subjectivity itself.

The second major development in 1980s cinema scholarship that contributes to this recent attention to precinematic spectatorship was the burgeoning interest in early cinema (Altman's "archaeology" period) as a neglected period of historical analysis. This trend can similarly be understood as a reaction against a dominant way of understanding U.S. film history, which privileges the so-called classical era of Hollywood cinema (most inclusively considered as spanning from approximately 1915 to 1960) as the telos of all previous (and thus underdeveloped or "primitive") cinematic forms. Already in 1977, Altman is critiquing this tendency in technical histories, which document innovators, or first appearances, of cinematic techniques (the close-up, crosscutting, etc.) as the first steps in the emergence of a stable vocabulary of film signification, long before such usages became semiotically standardized in the "classical" cinema (Altman 1977, pp. 5-6).

By the 1980s, this approach had come to seem overly systematized and reductive of both synchronic and diachronic divergences from-as well as competing structures within-the "classical" model. Scholars began to turn to earlier periods of cinema history, not simply to claw this era back into an organic model 
of growth and development toward a "mature" form, nor to point out a trajectory toward a consolidation of conventions, but instead to problematize this model. Increasingly, early cinema came to be considered not a "primitive" form of classical narrative cinema, but an entirely different type of spectacle with its own aesthetic and cultural specificity, which needed to be understood historically. Instead of contextualizing individual films and technical developments within an exclusively cinematic tradition, early cinema was historicized within a field of other cultural practices linked to modernity, which shared formal similarities, existed in similar social spaces, or relied upon a similar spectacular appeal or "shock effect." Historians of early cinema celebrated the lack of firmly consolidated filmic practices (both in terms of textual codes and exhibition or viewing conventions); the unsettled and sometimes unsettling aspects of these often rather bizarre films suggested a much wider range of possibilities of function or use within their cultural context. This in turn prompted a reconsideration of cinematic spectatorship in its earliest years as addressing and/or constructing a much different viewing subject than that which had been theorized more generally and universally, as described above. These historians of early cinema located cinema among a range of other entertainments, attractions, new public spaces and social practices that would inform our understanding of early spectators' rather different visual field, viewing habits, or cultural positioning as consumers of spectacle. ${ }^{6}$

A similar reconsideration of the writing of cinema's "prehistory" also attended this renewed interest in early cinema. As Altman notes (1977, p. 3), the early period of cinema, including the years before its invention, has traditionally been reduced to the terrain of technological history, which "attempts to chronicle the invention and commercialization of the mechanical apparatus necessary for the production and the projection of the film image." Most commonly, the precinematic era is thus recast as the protocinematic era, in which a number of primitive or failed devices and inventions stand as testimony to the teleological ideal of cinema that will initially be realized in 1895, and gradually be perfected through a series of further technological 
innovations during the ensuing century: "Zootropes and phenakistoscopes, panchromatic film and cinemascope, Muybridge and Edison, Lumière and Pathé-this is the technological historian's domain" (Altman 1977, pp. 3-4). Once again, this approach retroactively attributes greatest significance to those devices which seem to form obvious steps in the most direct progression toward modern cinema, while reducing others to missteps or failures, or even ignoring them altogether. But it is only with a directed hindsight that such evaluations can be made, of course, and narrativizing technology in this fashion tends to cast cinema as we know it as the logical or even "natural" outcome of history, rather than foregrounding cinema as itself an organizing principle of the historical field of technologies.

Another problem associated with this type of historiography is that it conceptually reduces all possible developmental influences on cinema to one realm, the technological, ignoring the overdetermination of factors such as economics, urbanization and industrialization, and other forms of entertainment. In this way, technological histories of the precinematic era would traditionally concentrate on the development of a litany of devices (sometimes going as far back as the camera oscura, or even Plato's cave) such as magic lantern shows, the thaumatrope, the phenakistoscope, the zootrope, still photography, Muybridge's zoopraxiscope, Marey's chronophotographic gun, Edison's kinetograph/kinetoscope, and Lumière's cinématographe, all of which in some way prefigure or contribute to the invention of "cinema."

More recent historicizations of the precinematic, and especially precinematic spectatorship, have rejected the central importance of an evolving technological (material) apparatus, and instead turn to a much wider cultural contextualization for cinema's eventual emergence: amusement parks, train travel, panoramas, folk museums, morgues, freak shows, department stores, serialized and illustrated newspaper stories, wax museums, traveling phonography, illustrated lectures, vaudeville, and so on. In these cases, the element frequently posited as shared with the eventual cinema is an audience, or a mode of viewing, 
rather than a particular apparatus or certain textual strategies which position the viewer.

These two trends in cinema scholarship of the late1980sthe attempt to historicize theorizations of spectatorship and the attempt to reconsider historical periods and objects from the perspective of cultural viewing positions-has spawned some extremely interesting work, much of it influenced by Foucault, the New Historicism, techniques of cultural history, and/or cultural studies more generally. ${ }^{7}$ And it is in continuation of this spirit that the articles collected here have been chosen. The growing reciprocity of cinema historiography and film theory (across a number of domains) suggests a possibility of reconfiguration for the discipline as a whole, where history and theory will not necessarily be opposed but force fundamental reassessments of accepted standards of "historical" or "theoretical" knowledge. But at the moment, this theoretical historiography-or historiographical theory-of early cinema spectatorship remains one of the few areas that is witnessing such a sustained interrogation, as the seven articles that follow amply demonstrate.

\section{(Early) Cinematic Apparatuses}

Opening and closing the issue are two articles which directly address the question of the continuing usefulness of the Baudrian/Metzian apparatus. Frank Kessler offers an excellent recapitulation of the broad strokes of this theoretical model and some of the problems that attend it; ultimately Kessler argues for the ongoing heuristic value of the apparatus when properly historicized in relation to spectatorial positioning. In a concluding, and even more expansive, article, Jean-Pierre Sirois-Trahan (coeditor of this issue of Cinémas) also details the problematic aspects of this concept. Sirois-Trahan usefully distinguishes between what he calls "apparatuses of reception" and "apparatuses of production" (dispositifs de réception et de production) in reconsidering how the evolution of the language of cinema has been conceptualized.

Between these two theoretical bookends, a number of fascinating historical case studies intervene, in which questions of 
historical modes of spectatorship are tackled in relation to specific visual apparatuses. Alison Griffiths focuses on the 19th century panorama (especially those featuring faraway places or historical events): the kind of spectatorial address they created and how this kind of viewing position related to genres of early cinematic spectacle. Tom Gunning offers a model of fascination-of the uncanny-associated with the phantasmagoria, where spectators were invited to question the certainties of their perceptions. Dan Streible's article on mutoscopes foregrounds a kind of social milieu (discursive and material) accompanying their consumption, particularly by children, across different historical periods. Both Jan Holmberg and Isabelle Raynauld compare early cinema with new media technologies of our own times, to demonstrate certain commonalities around their reception. Raynauld compares an early cinema text with a recent CD-ROM, highlighting how discourses of "newness" or novelty influence a medium's reception, before it is "institutionalized" or fully conventionalized for its audiences. Holmberg's comparison is between early cinema and video games, wherein textual aesthetics and the resultant viewer/player's experience of "immersion" is the crucial commonality-a trope that, for Holmberg, asks us to reconsider the totality of cinema's development around the desire for this experience.

Taken together, these articles demonstrate that careful historicization of a theoretical model of spectatorship can yield extremely fruitful results. Not only do the authors collectively contribute a great deal to our understanding of early cinema and other surrounding visual media, but they also point to the kinds of new theoretical questions that a serious engagement with historical spectatorship can yield.

University of Iowa

\section{NOTES}

1. Additional proceedings from this conference can be found in two other publications. See the special issue of Cinéma \& Cie: "Representational Technologies and the Discourse on Early Cinema's Apparatus/Les technologies de représentation et le discours sur le dispositif cinématographique des premiers temps" (Maule 2003); 
and André Gaudreault, Catherine Russell, and Pierre Véronneau (eds.), Le Cinématographe, nouvelle technologie $d u X X^{e}$ siècle/The Cinema, a New Technology for the 20th Century, Lausanne, Payot Lausanne, forthcoming in 2004.

2. I am referring to academic treatments within the then newly formed discipline of film studies. Of course, there were a number of "audience studies" produced by sociologists (and frequently used by moral pressure groups against Hollywood), going at least as far back as the era of the First World War, and becoming especially prevalent during the 1930s (most famously in the Payne Fund Studies). And Hollywood itself conducted audience research. See Handel 1950. Studies of these types represent contemporary social scientific work on movie audiences, often providing useful source information (acting themselves as historical documents) for later cinema historians.

3. For Jean-Louis Baudry, see Baudry 1985 and Baudry 1986. For Christian Metz, the sections of The Imaginary Signifier most relevant to the apparatus have been collected as excerpts. See Metz 1999 and Metz 1985. While Louis Althusser's work does not directly take up cinema, his influence on apparatus theory has been enormous. See Althusser 1998.

4. This "third generation," the "new practitioners" who apparently do not need to waste their time "build[ing] a base of knowledge," is apparently made up of young structuralist semioticians of the 1970s: "The sweep of generations was encapsulated, albeit imperfectly, at a landmark conference... in 1975, where, among the featured speakers, critic Andrew Sarris may be said to have represented the first generation, philosopher Stanley Cavell the second, and semiologist Umberto Eco-not as a member but as a signifier of changing discourses - the third" (Sklar 1990, p. 15).

5. Sklar looks at two works in this vein, and even uses the latter's findings to attack "the revisionists" one last time. See Ewen 1980 and Rosenweig 1983. See also Peiss 1986.

6. It is interesting to note that Miriam Hansen differentiates between the use of the terms "audience" and "spectator" not just as a theoretical or methodological distinction operative within viewer-oriented studies (as do Kuhn, Mayne, Staiger and others who posit the former as a "real" social collective and the latter as a hypothetical or ideal construct of the text); instead, Hansen argues that the emergence of the "spectator" (and concomitant suppression of the "audience" as such) is historically specific, marking a paradigm shift between early and later cinema (around 1909). See Hansen 1991 (pp. 23-24).

7. See for example Charney and Schwartz 1996; Williams 1994 (an anthology that includes relevant essays by Jonathan Crary, Anne Friedberg, and Tom Gunning); Crary 1994; Hansen 1991; Iris 1990 (a special issue on "Early Cinema Audiences"); Schivelbusch 1986; and Rabinovitz 1998.

\section{BIBLIOGRAPHICAL REFERENCES}

Althusser 1998: Louis Althusser, "Ideology and Ideological State Apparatuses," in Julie Rivkin and Michael Ryan (eds.), Literary Theory: An Anthology, Oxford, Blackwell, 1998, pp. 294-304.

Altman 1977: Charles F. Altman, "Towards a Historiography of American Film," Cinema Journal, Vol. 16, no. 2, 1977, pp. 1-25.

Baudry 1985: Jean-Louis Baudry, "Ideological Effects of the Basic Cinematographic Apparatus," in Bill Nichols (ed.), Movies and Methods, Berkeley, University of California Press, 1985, pp. 531-542. 
Baudry 1986: Jean-Louis Baudry, "The Apparatus: Metapsychological Approaches to the Impression of Reality in Cinema," in Philip Rosen (ed.), Narrative, Apparatus, Ideology, New York, Columbia University Press, 1986, pp. 299-318.

Charney and Schwartz 1996: Leo Charney and Vanessa R. Schwartz (eds.), Cinema and the Invention of Modern Life, Berkeley, University of California Press, 1996.

Crary 1994: Jonathan Crary, Techniques of the Observer: On Vision and Modernity in the Nineteenth Century, Cambridge, MIT Press, 1994.

Ewen 1980: Elizabeth Ewen, "City Lights: Immigrant Women and the Rise of the Movies," Signs: Journal of Women in Culture and Society, Vol. 5, no. 3, 1980.

Handel 1950: Leo Handel, Hollywood Looks at Its Audience, Urbana, University of Illinois Press, 1950.

Hansen 1983: Miriam Hansen, "Early Silent Cinema: Whose Public Sphere?," New German Critique, no. 29, 1983, pp. 147-184.

Hansen 1991: Miriam Hansen, Babel and Babylon: Spectatorship in American Silent Film, Cambridge, Harvard University Press, 1991.

Iris 1990: Iris, "Early Cinema Audiences," Vol. 6, no. 2, 1990.

Marcuse 1994: Herbert Marcuse, "Some Social Implications of Modern Technology," in Andrew Arato and Eike Gebhardt (eds.), The Essential Frankfurt School Reader, New York, Continuum, 1994.

Maule 2003: Rosanna Maule (ed.), "Representational Technologies and the Discourse on Early Cinema's Apparatus/Les technologies de représentation et le discours sur le dispositif cinématographique des premiers temps," Cinéma \& Cie, no. 3, 2003.

Mayne 1982: Judith Mayne, "Immigrants and Spectators," Wide Angle, Vol. 5, no. 2, 1982, pp. 32-40.

Metz 1985: Christian Metz, "Story/Discourse: Notes on Two Kinds of Voyeurism," in Bill Nichols (ed.), Movies and Methods, Berkeley, University of California Press, 1985, pp. 543-548.

Metz 1999: Christian Metz, "Identification, Mirror," "The Passion for Perceiving," and "Disavowal, Fetishism," in Leo Braudy and Marshall Cohen (eds.), Film Theory and Criticism, New York, Oxford University Press, 1999, pp. 800-817.

Peiss 1986: Kathy Peiss, Cheap Amusements: Working Women and Leisure in Turn-ofthe-Century New York, Philadelphia, Temple University Press, 1986.

Rabinovitz 1998: Lauren Rabinovitz, For the Love of Pleasure: Women, Movies and Culture in Turn-of-the-Century Chicago, New Brunswick, Rutgers University Press, 1998.

Rosenweig 1983: Roy Rosenweig, Eight Hours for What We Will: Workers and Leisure in an Industrial City, 1870-1920, Cambridge, Cambridge University Press, 1983.

Schivelbusch 1986: Wolfgang Schivelbusch, The Railway Journey: The Industrialization of Time and Space in the 19th Century, Berkeley, University of California Press, 1986.

Sklar 1990: Robert Sklar, "Oh! Althusser!: Historiography and the Rise of Cinema Studies," in Robert Sklar and Charles Musser (eds.), Resisting Images: Essays on Cinema and History, Philadelphia, Temple University Press, 1990, pp. 12-35.

Williams 1994: Linda Williams (ed.), Viewing Positions, New Brunswick, Rutgers University Press, 1994. 